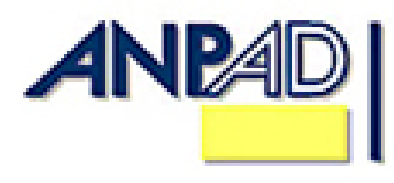

Available online at

http://www.anpad.org.br/bar

BAR, Rio de Janeiro, v. 11, n. 2, art. 4, pp. 188-209, Apr./June 2014

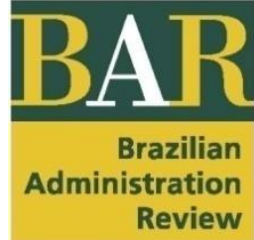

$(\mathrm{ccc}) \mathrm{E}$.

\title{
The Determinants of Credit Rating: Brazilian Evidence
}

Flávia Cruz de Souza Murcia

E-mail address: flavia_c_souza@hotmail.com

Universidade Federal de Santa Catarina - CPGA/UFSC

UFSC, Campus Universitário Trindade, 88040-900, Florianópolis, SC, Brazil.

Fernando Dal-Ri Murcia

E-mail address: fernandomurcia@hotmail.com

Universidade de São Paulo - PPGCC/FEA/USP

USP, Av. Prof. Luciano Gualberto, 908, 05508-010, São Paulo, SP, Brazil.

Suliani Rover

E-mail address: suliani.rover@ufsc.br

Universidade Federal de Santa Catarina - PPGC/UFSC

UFSC, Campus Universitário Trindade, 88040-900, Florianópolis, SC, Brazil.

José Alonso Borba

E-mail address: j.alonso@ufsc.br

Universidade Federal de Santa Catarina - PPGC/UFSC

UFSC, Campus Universitário Trindade, 88040-900, Florianópolis, SC, Brazil.

Received 11 December 2012; received in revised form 11 October 2013 (this paper has been with the authors for two revisions); accepted 15 October 2013; published online $1^{\text {st }}$ April 2014. Editor's note. Ricardo Pereira Câmara Leal served as Associate Editor for this article. 


\begin{abstract}
This study attempts to identify the determinant factors of credit rating in Brazil. The relevance of this proposal is based on the importance of the subject as well as the uniqueness of the Brazilian market. As for originality, the great majority of previous studies regarding credit rating have been developed in the US, UK and Australia; therefore the effect on other markets is still unclear, especially in emerging markets, like Brazil. We've used a Generalized Estimating Equations (GEE) model considering a panel structure with a categorical dependent variable (credit rating) and ten independent variables: leverage, profitability, size, financial coverage, growth, liquidity, corporate governance, control, financial market performance and internationalization. The sample consisted of 153 rating observations during the period of 1997-2011 for a total of 49 public firms operating in the Brazilian Market. Results showed that leverage and internationalization are significant at the $1 \%$ level in explaining credit rating. Performance in the financial market was significant at a 5\% level; profitability and growth were also statistically significant, but at a $10 \%$ significance level.
\end{abstract}

Key words: credit rating; determinants; Brazil. 


\section{Introduction}

Credit rating agencies play an important role in modern financial markets since they are institutions with privileged access to private information about security issuers thanks to their screening processes (Calderoni, Colla, \& Gatti, 2009). According to Kang and Liu (2007), credit ratings have been broadly embraced by financial markets because the levels and changes in ratings are likely to predict the likelihood of defaults. Regarding this aspect, prior studies have showed that default risk has a significant association with the ratings assigned by agencies.

In the market view, rating agencies are expected to be independent third parties in the borrower/lender relationship, which evaluates the financial condition of the debt issuer. In fact, as López (2007) states, new laws and regulations recommend the use of external ratings by supervisory authorities as relevant information to control the financial solvency of the entities themselves.

Papaikonomou (2010) certifies that, undoubtedly, credit rating agencies can provide a valuable service for capital markets if they deliver a credible and independent assessment of the relative default probability of financial credit instruments that enables investors to reduce the information asymmetry they face vis-à-vis borrowers. Investors should be able to make better decisions as they can differentiate good quality security from lemons. In this sense, one expects rating agencies to contribute to a more efficient resource allocation in the economy.

Due to the evolution of financial markets and the correspondent increase in regulation, rating agencies are becoming more important on a global scale. In spite of the drop in the cost of acquiring information, owing to technological progress, the role of global credit rating agencies is thus becoming even more fundamental for the working of world financial markets (Ferri \& Liu, 2002).

According to Poon and Chan (2008) one strand of credit rating research focuses on the determinants. This literature focuses on the predictability of credit rating changes based on companies' financial information and capital market conditions. It primarily uses deterministic models such as discriminant and cluster analyses to investigate the underlying determinants of credit ratings. This deterministic model approach assumes that the financial analysts of credit rating agencies use all of the accounting information of the issuer as well as capital market conditions in determining the credit rating of a particular company.

Gray, Mirkovic and Ragunathan (2006) state that there is a substantial literature that seeks to quantify the relationship between financial and industry data, and credit ratings that has progressed with the development of econometric techniques for analyzing categorical dependent variables.

This line of research that uses financial ratios and firm characteristics to explain the ratings has appeared primarily in the accounting and finance literature (Bouzouita \& Young, 1998). In these papers, credit rating is a proxy for credit risk and consequently tends to be influenced by variables related to a company's financial position, as well as qualitative variables that are taken into account by rating agencies. Among these studies, it is worthwhile to mention the seminal paper of Altman (1968, p. 594), entitled "Financial Ratios, Discriminant Analysis and the Prediction of Corporate Bankruptcy", that used a model with accounting ratios to discriminate solvents and insolvent companies.

Along this line of thinking, the aim of this study is to identify the determinants of credit rating in Brazil. As for relevance, Kim and Gu (2004, p. 96) ensure that "a model capable of predicting bond rating would enable firms to identify factors affecting their bond ratings and take actions to reduce the perceived risk and lower the cost of borrowing". Kaplan and Urwitz (1979) believe that a measure of a firm's credit risk is an important dependent variable for study and that bond ratings do capture a significant aspect of credit risk. 
For Adams, Burton and Harwick (2003), insights into the determinants of credit ratings could assist industry regulators, policyholders, and investors when deciding whether or not to rely on the ratings assigned by credit rating firms. It is argued that investors could adjust their investment portfolio based on the results presented by credit rating models.

This study is also relevant due to the incipience of credit rating studies in the Brazilian Market. According to Creighton, Gower and Anthony (2007) most previous studies have used data from the United States, where there is a more significant role for credit ratings. While there is no previous work on this topic relating to emerging markets, "there is substantial literature in mature markets (mainly the United States) on the relationship between rating changes and their effects on bond and stock prices" (Richards \& Deddouche, 2003, p. 339).

According to Han, Shin, Reinhart, and Moore (2009), credit ratings, especially those issued by Standard \& Poor's and Moody's are critical to international investors who wish to invest in corporate debt from emerging markets because: (a) financial information in emerging markets is much less transparent than in developed markets, (b) there are no reliable financial institutions in emerging markets that can certify the eligibility of a debt to international investors; (c) many foreign institutional investors are not allowed to invest in speculative grade bonds in emerging markets, and (d) bank regulators use ratings for financial regulation and supervision and capital adequacy rules.

Furthermore, the Brazilian market has some specific characteristics that can lead to different results than those founded in other markets. Note, for example, that Brazil has adopted a Code Law legal system, mainly derived from Portugal. According to prior research regarding law and finance (La Porta, Lopes-de-Silanes, Schleifer, \& Vishny, 1997, 1999, 2000, 2002), code law countries have: (a) less developed equity markets; (b) firms with more concentrated control; (c) a lower number of publicly traded companies and smaller number of initial public offering each year; (d) more companies penalized by investors in the valuation process; and (e) companies that pay lower dividends.

According to Lopes and Walker (2012), the Brazilian Market is characterized by low enforcement, incentives for manipulation of financial statements due to tax influences, an unstable financial market and poor governance standards. In this sense, it is not clear if credit rating has a significant role in the Brazilian Market. Moreover, note also the economic importance that Brazil has been gaining in the global economy, due to high economic growth rates presented in recent years, inflation being under control and the stability of its financial institutions. In 2012, Brazil became the $7^{\text {th }}$ largest economy. In short, the Brazilian market presents a unique setting for conducting studies on credit rating.

\section{Literature Review}

The word risk has its origins in the sixteenth-century Europe, during the Renaissance, and derives from the Italian word risicare, which in turn has its origin in the Latin risicu, riscu, which means to dare. In this sense, risk is a choice, not a fate (Bernstein, 1997).

According to Guerron-Quintana (2011, p. 10), in the field of Economics, risk was seminally discussed by Frank Knight in 1921, in his book entitled "Risk, Uncertainty, and Profit". Knight outlined the difference between risk - unknown outcomes whose probability of happening can be measured, or at least have a good knowledge - and uncertainty - uncertain events that people do not know how to describe.

Specifically in the financial market, the word risk is often related to the possibility of an investment loss. In the seminal work of Markowitz (1952), for example, risk was related to uncertainty, represented by the variability of the expected return of a given asset. 
Credit risk, in turn, is associated with the fulfillment of the obligations to the lender. According to Sales (2006), the concept of credit risk can be understood as the probability of an issuer to default, leading to non-payment of interest and/or principal.

In financial markets, investors are often interested in measuring the risk of a company or country to decide about possible investments (Sih, 2006). According to Callado, Vasconcelos, Rodrigues and Libonati (2008) since the 1980's, the demand for information related to credit risk analysis has increased dramatically in the international financial market, and from that demand, several methodologies have been developed.

Credit ratings express the agency's opinion about the ability and willingness of an issuer to meet its financial obligations in full and on time (Standard \& Poor's, 2011). Jorion, Liu and Shi (2005) agree with this concept when they state that ratings express the opinion of the future ability, legal obligation, and willingness of a bond issuer or other obligor to make full and timely payments on principal and interest due to investors. According to Gray et al. (2006), a corporate credit rating is an independent evaluation of a firm's ability to make debt payments in a timely fashion. In this context, credit rating can also be understood as a relative measure of credit risk, based on the analysis of quantitative and qualitative variables (Sales, 2006).

According to Kim and Gu (2004) the bond rating is an indicator of a firm's default risk. Choy, Gray and Ragunathan (2006) claim that studies on rating trends demonstrate that there is a clear correlation between credit ratings and the likelihood of subsequent default, that is, the higher the initial rating, the lower the probability of default and vice versa.

Commonly, ratings are defined by symbols, and the same symbols are used for both corporate and bond ratings. Table 1 shows the rating categories used by Standard \& Poor's (S\&P), Moody's and Fitch.

Table 1

\section{Ratings Definitions}

\begin{tabular}{|c|c|c|}
\hline & S\&P and Fitch/Moody's & DESCRIPTION \\
\hline \multirow{4}{*}{ 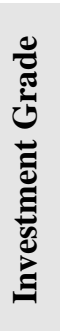 } & AAA/Aaa & Extremely strong capacity to meet financial commitments. Highest rating. \\
\hline & $\mathrm{AA} / \mathrm{Aa}$ & Very strong capacity to meet financial commitments. \\
\hline & $\mathrm{A} / \mathrm{A}$ & $\begin{array}{l}\text { Strong capacity to meet financial commitments, but somewhat susceptible to } \\
\text { adverse economic conditions and changes in circumstances. }\end{array}$ \\
\hline & $\mathrm{BBB} / \mathrm{Baa}$ & $\begin{array}{l}\text { Adequate capacity to meet financial commitments, but more subject to } \\
\text { adverse economic conditions. }\end{array}$ \\
\hline \multirow{6}{*}{ 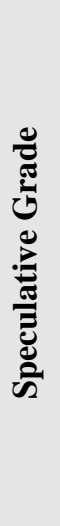 } & $\mathrm{BB} / \mathrm{Ba}$ & $\begin{array}{l}\text { Less vulnerable in the near-term but faces major ongoing uncertainties to } \\
\text { adverse business, financial and economic conditions. }\end{array}$ \\
\hline & $\mathrm{B} / \mathrm{B}$ & $\begin{array}{l}\text { More vulnerable to adverse business, financial and economic conditions but } \\
\text { currently has the capacity to meet financial commitments. }\end{array}$ \\
\hline & $\mathrm{CCC} / \mathrm{Caa}$ & $\begin{array}{l}\text { Currently vulnerable and dependent on favorable business, financial and } \\
\text { economic conditions to meet financial commitments. }\end{array}$ \\
\hline & $\mathrm{CC} / \mathrm{Ca}$ & Currently highly vulnerable. \\
\hline & $\mathrm{C} / \mathrm{C}$ & $\begin{array}{l}\text { A bankruptcy petition has been filed or similar action taken, but payments of } \\
\text { financial commitments are continued. }\end{array}$ \\
\hline & D/- & Payments default on financial commitments. \\
\hline
\end{tabular}

Note. Source: The descriptions presented in the Table 1 were collected from Standard \& Poor's Ratings Services. (2011). Guide to credit rating essentials: what are credit ratings and how do they work? Retrieved from http://img.en25.com/Web/StandardandPoors/SP_CreditRatingsGuide.pdf; however, they are very similar to the ones 
presented by Fitch Ratings. (n.d.). Ratings internacionais de crédito de longo prazo. Retrieved from http://www.fitchratings.com.br/pages/rtg_intl_long and Moody's Investors Service. (2013). Ratings symbols and definitions. Retrieved from https://www.moodys.com/researchdocumentcontentpage.aspx?docid=PBC_79004

The agencies S\&P and Fitch emphasize that ratings from AA to CCC may be modified by the addition of positive (+) and negative (-) signs to show the relative position within the rating categories. Moody's (2013) notes that ratings can also be changed from the addition of numbers 1, 2 and 3 for each category from Aa through Caa, in order to show the relative position of each rating within the category.

According to Camargo (2009), due to the sophistication of financial instruments, agencies have sought to improve their criteria and methodologies. Gray et al. (2006) argue that the rating standards used by agencies are increasing over time; in other words, as agencies are becoming more rigorous, a firm would need to improve its financial ratios over time just to maintain its credit rating.

To formulate their opinions on companies' credit risk, rating agencies use different methodologies. Some focus only on quantitative data, which are incorporated into mathematical models. Others use both quantitative and qualitative information obtained through meetings with company/government personnel (Standard \& Poor's, 2011). This second approach uses a set of criteria consisting of principles, methodologies and assumptions. According to Standard \& Poor's (2010), the principles are the fundamental elements for the analysis of credit risk and the treatment of quantitative and qualitative information; methodologies are specific methods that govern the application of the principles to a specific rating; and assumptions are projections, estimates and parameters used in the models.

Is it important to mention that credit risk can also be measured using other methodologies. For instance, it can be measured by risk premium embedded in Yield-to Maturity (YTM) of corporate bonds, which is based on an equilibrium model instead of a credit rating based on a corporate decision. In approach, the yield-to-maturity (YTM) of a fixed-rate bond is defined as the constant internal rate of return that recovers the price. Using this concept, one can compute a spread measure by comparing the YTM of a risky bond to that of a hypothetical treasury bond, risk free, with the same maturity as the risky bond. This hypothetical bond is determined by interpolating with a reference curve that is constructed from benchmark Treasury securities.

It is worth mentioning that the importance of corporate credit rating can be analyzed from the perspective of companies receiving the rating, investors, regulators or even taking into account the view of the market as a whole.

From the company perspective, a credit rating has great practical importance since it impacts the firm's cost of debt, its financing structure, and even its ability to continue trading (Gray, Mirkovic, \& Ragunathan, 2006). The rationale here is that the cost of debt becomes more expensive as the rating deteriorates. For this reason, the rating also impacts managers' decisions on new loans and financing.

According to Kang and Liu (2007), also from the company view, monitoring exercised by rating agencies may supplement payment schemes based on shares and other corporate governance mechanisms to discipline CEOs. This constant monitoring exercised by rating agencies tends to influence management to act in the interest of shareholders to maximize the value of the firm. In other words, credit rating does have a corporate governance function.

In the view of investors, "ratings are the principal source of information about the "quality" and marketability of various bond issues" (Pinches \& Singleton, 1978, p. 29), as rating agencies have access to confidential information that is not available to the market. This can potentially increase the value of credit ratings to the public (Jorion, Liu, \& Shi, 2005).

Credit rating literature suggests that they serve two purposes: to certify a company's existing financial condition to investors (initial rating) and signal a change in a company's prevailing financial condition (rating changes) (Poon \& Chan, 2008). 
Regulators, like investors, use credit ratings to save resources they would otherwise devote to credit evaluation. In particular, regulators employ a variety of specific ratings as thresholds for determining capital charges and investment prohibitions on institutional portfolio holdings (Cantor \& Packer, 1997). In fact, regulators recognize that the major financial market participants use such credit ratings as a reference for the calculation of their capital requirements for solvency purposes or for calculating risks in their investment activity (Papaikonomou, 2010).

Finally, the credit rating agencies have an important role to play in supplementing the solvency monitoring systems of insurance industry regulators, as well as enhancing the screening and monitoring activities of investment analysts and providers of corporate debt (Adams, Burton, \& Harwick, 2003). To the extent that they are specialists in obtaining and processing information about default risk, rating agency actions reduce lenders' information-gathering costs and thereby facilitate securities markets operations (Creighton, Gower, \& Anthony, 2007, pp. 1-2). Table 2 presents prior studies on determinants of credit rating.

Table 2

\section{Reference Literature Regarding Determinants of Credit Rating}

\begin{tabular}{|c|c|c|}
\hline AUTHORS & SAMPLE & SIGNIFICATIVE VARIABLES \\
\hline $\begin{array}{l}\text { Bouzouita and } \\
\text { Young (1998) }\end{array}$ & $\begin{array}{l}\text { US insurance companies that } \\
\text { received a rating from the A.M. Best } \\
\text { in 1989-1992. }\end{array}$ & $\begin{array}{l}\text { Profitability, Growth in surplus, Leverage, Line } \\
\text { mix, Liquidity, Size, Organizational form }\end{array}$ \\
\hline $\begin{array}{l}\text { Adams, Burton and } \\
\text { Hardwick (2003) }\end{array}$ & $\begin{array}{l}\text { UK insurance companies that } \\
\text { received a rating from the A.M. Best } \\
\text { and } S \& P \text {. }\end{array}$ & $\begin{array}{l}\text { Capital adequacy, Profitability, Liquidity, } \\
\text { Growth, Size, Reinsurance, Organizational form, } \\
\text { Business activity }\end{array}$ \\
\hline $\begin{array}{l}\text { Bhojraj and } \\
\text { Sengupta }(2003)\end{array}$ & $\begin{array}{l}\text { Industrial bond issues that received a } \\
\text { rating from 1991-1996. }\end{array}$ & $\begin{array}{l}\text { Institutional ownership, Proportion of the board } \\
\text { consisting of outsiders, Concentrated ownership, } \\
\text { Debt/Equity, Profit margin, Total assets, Market } \\
\text { value of common equity/Book of common equity }\end{array}$ \\
\hline Kim and Gu (2004) & $\begin{array}{l}25 \text { casino and hotel firms that had } \\
\text { ratings by Moody's from 1996-2001. }\end{array}$ & Debt service coverage, Profitability, Size \\
\hline Roje (2005) & $\begin{array}{l}\text { Firms that have credit ratings in years } \\
1998-2002 .\end{array}$ & $\begin{array}{l}\text { Return on assets, Return on equity, Profit, Market } \\
\text { value of equity, Tangible book value/Assets, } \\
\text { Leverage, Long term debt/Total assets, Projected } \\
\text { benefit obligation-pension plan assets/Total } \\
\text { assets, Volatility of earnings }\end{array}$ \\
\hline $\begin{array}{l}\text { Ashbaugh-Skaife, } \\
\text { Collins and LaFond } \\
(2006)\end{array}$ & $\begin{array}{l}\text { Firms with different corporate } \\
\text { governance levels that received } \\
\text { ratings by } S \& P \text {. }\end{array}$ & $\begin{array}{l}\text { Number of outside blockholders, Quality } \\
\text { accruals, Timeliness of firms' earnings, } \\
\text { Independence of board, CEO power, Percentage } \\
\text { of shares held by officers or directors, Board } \\
\text { expertise, Leverage, Return on assets, Net income } \\
\text { before extraordinary items, Size, Subordinated } \\
\text { debt, Interest coverage }\end{array}$ \\
\hline $\begin{array}{l}\text { Gray, Mirkovic and } \\
\text { Ragunathan (2006) }\end{array}$ & $\begin{array}{l}\text { Australian firms that received ratings } \\
\text { by S\&P from } 1995 \text { through } 2002 \text {. }\end{array}$ & $\begin{array}{l}\text { Interest coverage, Leverage, Profitability, } \\
\text { Industry concentration }\end{array}$ \\
\hline Sales (2006) & 44 Brazilian banks. & $\begin{array}{l}\text { Total assets, Equity, Deposits, Gross profit, Net } \\
\text { profit, Operating profit }\end{array}$ \\
\hline Sih (2006) & Firms that operate in the USA. & Industry, Cash, Market value \\
\hline Bone (2007) & Only Petrobrás (2007). & Interest coverage, Short-term debt/Total debt \\
\hline Bone (2010) & Only Repsol-YPF (2010). & \\
\hline López (2007) & Financial firms that operate in Europe. & Reinsurance, Profitability \\
\hline
\end{tabular}


Table 2 (continued)

\begin{tabular}{lll}
\hline AUTHORS & SAMPLE & SIGNIFICATIVE VARIABLES \\
\hline $\begin{array}{l}\text { Damasceno, Artes } \\
\text { and Minardi (2008) }\end{array}$ & 39 firms that operate in Brazil. & $\begin{array}{l}\text { Ibovespa participation, Total gross debt + Other } \\
\text { liabilities/Total assets, Return on assets }\end{array}$ \\
$\begin{array}{l}\text { Shiu and Chiang } \\
(\mathbf{2 0 0 8 )}\end{array}$ & $\begin{array}{l}\text { Firms that make up the Lloyd's } \\
\text { Market. }\end{array}$ & $\begin{array}{l}\text { Leverage, Reinsurance, Concentration index, } \\
\text { Profitability, Liquidity, Growth, Size }\end{array}$ \\
$\begin{array}{l}\text { Bone and Ribeiro } \\
(\mathbf{2 0 0 9 )}\end{array}$ & 16 non-financial Brazilian firms. & Total debt/EBITDA, Net cash flow/Total debt \\
$\begin{array}{l}\text { Matousek and } \\
\text { Stewart (2009) }\end{array}$ & 681 international banks. & $\begin{array}{l}\text { Equity/Total assets, Liquidity, Size, Net interest } \\
\text { margin, Operating expense/Operating profit, } \\
\text { Return on assets }\end{array}$ \\
\hline
\end{tabular}

Finally, is worthwhile mentioning that credit agencies have been criticized due to their failure to accurately predict and warn investors about companies' financial difficulties. For instance, some banks that filed for bankruptcy during the 2008 crisis had investment grade ratings. For Bone and Ribeiro (2009), the rating classification process lacks transparency, leading to the question of what are the relevant factors taken into consideration by the agencies.

It is also argued that agencies do not have incentives to seek detailed information about debt issuers, given the high cost of new information. Thus, agencies tend to follow only the market risk, rather than company-specific risk. In this case, market participants argue that ratings are predictable, since they only reproduce the sensitivity found in the market, and don't have any inherent informational content.

\section{Methodology}

Description of this study's methodological aspects is divided into three parts. First, we describe the hypotheses, together with their theoretical justifications. Second, the model, statistical technique, variables and proxies are discussed. Finally, data collection steps and the study's sample are presented.

\section{Hypotheses development}

To identify the determinants of credit ratings, ten hypotheses were formulated, which are presented below.

\section{Leverage}

H1: Less leveraged firms have better credit ratings.

Firms finance their operations with liabilities and equity. In general, as you increase the level of debt in the capital structure of an entity, other variables held constant, the company becomes riskier. Therefore, we expect a negative relationship between credit ratings and debt level.

According to Bouzouita and Young (1998), a high level of leverage increases the probability of default and the adverse variations in underwriting and/or economic conditions may, therefore, affect the rating. Shiu and Chiang (2008) add that a firm with high debt tends to have a high financial uncertainty and consequent high risk of insolvency. 
Gray et al. (2006) argue that the greater the degree of financial leverage, the smaller the cushion the firm has with respect to any unanticipated changes to its fortunes. Thus, higher leverage is usually associated with lower credit ratings.

\section{Profitability}

H2: More profitable firms have better credit ratings.

Generally, a profitable firm has a greater ability to generate cash to meet its financial obligations (Gray et al., 2006). In this context, we expect a positive relationship between credit rating and profitability.

According to Bouzouita and Young (1998, p. 26) "profitability reflects the ability of management to maintain strong operation and adequate pricing". In this sense, companies that experience a sustained increase in the level of their surplus are more likely to receive a better rating.

Adams et al. (2003) point out that examination of profitability enables financial analysts and industry regulators to assess a firm's ability to invest annual surpluses efficiently in order to generate new business. Furthermore, measures of profitability also provide insights into management's ability to control expenses effectively and to set competitive rates of premium.

\section{Size}

H3: Larger firms have better credit ratings.

As observed in business practice, large companies have easier access to credit and are considered important for the economy of a country as a whole. Thus, they tend to receive aid from the government, as they are to big to fail.

Moreover, Bouzouita and Young (1998, p. 27) argue that "large companies are better able to sustain unfavorable changes in economic conditions". Bhojraj and Sengupta (2003) agree when they mention that large companies have high ratings because of their low market risks. Kim and Gu (2004) found a positive relationship between size and rating. According to these authors, this is due to their better ability to minimize the impact of economic, social, and political changes.

\section{Financial coverage}

H4: Firms with higher financial coverage have better credit ratings.

The financial coverage indicators attempt to capture a company's ability to generate cash flow to pay interest expenses (Bone, 2007). Therefore, we expected financial cover to be positively correlated to a credit rating.

According to Gray et al. (2006) credit ratings tend to be highly sensitive to a firm's interest coverage ratio; thus firms with higher coverage ratios are likely to have higher credit ratings. For Ashbaugh-Skaife, Collins and LaFond (2006) as a company's operating cash flow declines, the default risk increases, leading to lower credit ratings. Thus, a low level of financial coverage may represent high risk.

\section{Growth}

H5: Firms with higher growth rates have better credit ratings.

According to Adams et al. (2003) higher growth rates are associated with higher credit ratings because it indicates a strong future cash flow performance and higher economic value. In the same 
view, Bouzouita and Young (1998, p. 26) claim that "firms who experience a sustained increase in the level of their surplus are more likely to receive a better rating".

\section{Liquidity}

H6: Firms with greater liquidity have better credit ratings.

"A high degree of liquidity enables the insurer to meet unexpected needs for cash without having to sell assets at a discounted value" (Bouzouita \& Young, 1998, p. 27). In general, higher liquidity indicates that a firm has a better ability to cover short-term liabilities with current assets that can be transformed into money much faster than long-term assets (Roje, 2005). Empirical evidence shows that liquidity is an important factor in the corporate decision to obtain a credit rating (Adams et al., 2003).

\section{Corporate governance}

H7: Firms with better corporate governance have better credit ratings.

According to Bhojraj and Sengupta (2003) an effective corporate governance mechanism can affect bond yields and ratings through its impact on default risk. The rationale is that companies with good governance practices would be seen as the most reliable companies, with a higher level of disclosure and transparency.

Also, governance mechanisms tend to reduce potential conflicts of interests between management and providers of capital through effective monitoring of their actions. This can reduce expropriation and misallocation of funds, improve the firm's productivity and disclosures and provide management with a long-term planning horizon. All these could be perceived positively by bondholders, resulting in a reduction in the firms' perceived default risk, therefore improving credit rating.

\section{Control}

H8: State-controlled firms have better credit ratings than private firms.

It can be argued that state-controlled enterprises are less likely to default as they tend to get help from state in bad times. Moreover, in Brazil, many companies that provide basic services to the population (electricity, water etc.) are controlled (i.e. majority of ordinary shares) by the government. As we know, these services are essential to the population, which makes default and or bankruptcy a 'political' event, which tends to be avoided by politicians in power.

Is it is worthwhile to mention that this hypotheses has not been tested in prior studies and therefore the link between government control and credit rating is not quite clear in the existing literature.

\section{Performance in the financial market}

H9: Best performing firms in the financial market have better credit ratings.

Rating agencies use both quantitative and qualitative variables to evaluate a company (Standard $\&$ Poor's, 2010). However, they do not clearly disclose the variables they use; and even if they did, perhaps most of them, it would be difficult to measure. For instance, a change of CEO, a strategic repositioning or the presence of new outside directors could generate improvement in companies' financial conditions to honor their debts. 
Thus, good performance in financial markets could reflect improvements that would be difficult to capture by other measures. According to the Efficient Market Hypothesis (EMH), the market absorbs information immediately, quickly reflecting any new relevant facts in stock prices. In this context, a company's value is influenced by any new information that is relevant.

In this sense, performance in financial markets could be related to corporate rating, because both are affected by new relevant information. Although the relationship might not be direct (rating-pricerating) as already highlighted, several kinds of qualitative information taken into account by agencies, which are difficult to model, should also impact share price.

For this reason, we've chosen to use a variable related to performance in financial markets in order to capture the effects of all new information that impact the stock price. It is worth mentioning that the inclusion of this variable is unprecedented in determinant rating studies and has not been tested previously by other authors.

\section{Internationalization}

H10: Firms that issues ADRs have better credit ratings.

Several Brazilian companies have sought to diversify their portfolio of investors by issuing American Depositary Receipts (ADR) and obtaining resources in the US market through the dual listing of shares. Camargos, Gomes and Barbosa (2003) argue that the lack of long-term funds in the Brazilian market has been the leading factor for the issuance of ADRs by Brazilian companies. Also, as known, companies aim to obtain international visibility and cheaper capital.

According to Coffee (1999), firms use ADR to help attract more capital through external financing. The author also claims that the supervision by the Securities and Exchange Commission (SEC) and U.S. sanction laws can protect minority shareholders, deterring potential fraud involving foreign companies listed on U.S. capital market, thus minimizing agency cost.

It is worth mentioning that foreign companies that trade ADRs in levels II and III are also subject to the requirements of Sarbanes-Oxley (SOX) Act 2002, among which one can highlight: arrangement of an audit committee, the presence of a financial expert on the board of directors, strengthening of controls, higher disclosure requirements, etc.

In this sense, we expect the impacts of lower cost of capital, international visibility, better governance practices and SEC supervision, all resulting from cross listing in the US, to be positively related to corporate rating.

\section{Statistical technique}

According to Gujarati (2006) a variable can be treated as ordinal when its values represent categories with some intrinsic ranking like a degree of satisfaction. Although degree of satisfaction is not a scale variable, one is able to order the different levels in a ranking: high level, medium level, etc. This is the same with credit ratings, which are presented in terms of categories (AAA, AA etc.) that can be seen as a result of a continuous variable capacity to honor debt obligations.

The Generalized Estimating Equations (GEE) was first introduced by Liang and Zeger (1986) as a method of estimation of regression model parameters when dealing with correlated data. Regression analyses with the GEE methodology are commonly chosen when the outcome of the measure of interest is discrete, like a credit rating, rather than continuous.

GEE is used to estimate marginal or population-averaged effect dependence, as parameter estimates from GEE are consistent even when the covariance structure is misspecified, under mild regularity conditions. Dependence among the responses for units in a given cluster is taken into 
account but treated as a nuisance, whereas this dependence is of central interest in multilevel modeling.

In this sense, the GEE is appropriate for this study, as data was collected across successive points in time; thus, if this correlation is not taken into consideration, the model will not be valid.

Camargo (2009) highlights that, to use the information in rating regressions, several authors have transformed ratings into numerical values. By doing so, one obtains an ordinal variable, a type of non-metric scaling, which may be ordered. Following this same line of thinking, Silva, Santos, Torres, and Ferreira (2009) mention that the conversion of credit ratings into numerical values allows the equivalence between the ratings issued by different credit rating agencies. They also emphasize that the numbers used only indicate the relative positions of an ordered series.

Some previous studies (Ashbaugh-Skaife, Collins, \& LaFond, 2006; Damasceno, Artes, \& Minardi, 2008; Silva, Santos, Torres, \& Ferreira, 2009) have opted to split the ratings into seven groups, which we have also done in the present study.

However, very few companies were assigned ratings of 1,2 and 6 . In this sense, for technical reasons related to parameter estimation, ratings classes were redefined by incorporating ratings 1 and 2 into class 3 and rating 6 into class 5 . In this sense, a three-level classification has been used in this paper, as shown in Table 3.

Table 3

Dependent Variable Classes

\begin{tabular}{|c|c|c|c|c|}
\hline & $\mathbf{S} \& \mathbf{P}$ & MOODY'S & OLD CLASSES & NEW CLASSES \\
\hline \multirow{10}{*}{ 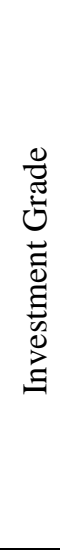 } & AAA & Aaа & & \multirow{10}{*}{3} \\
\hline & $\mathrm{AA}+$ & Aa1 & 7 & \\
\hline & AA & $\mathrm{Aa} 2$ & $r$ & \\
\hline & AA- & $\mathrm{Aa} 3$ & & \\
\hline & A+ & $\mathrm{A} 1$ & \multirow{3}{*}{6} & \\
\hline & A & A2 & & \\
\hline & A- & $\mathrm{A} 3$ & & \\
\hline & $\mathrm{BBB}+$ & Baa1 & \multirow{3}{*}{5} & \\
\hline & BBB & Baa2 & & \\
\hline & BBB- & Baa3 & & \\
\hline \multirow{12}{*}{ 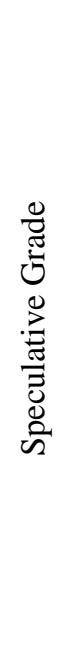 } & $\mathrm{BB}+$ & Ba1 & \multirow{3}{*}{4} & \multirow{3}{*}{2} \\
\hline & $\mathrm{BB}$ & $\mathrm{Ba} 2$ & & \\
\hline & BB- & $\mathrm{Ba} 3$ & & \\
\hline & $\mathrm{B}+$ & B1 & \multirow{3}{*}{3} & \multirow{9}{*}{1} \\
\hline & $\mathrm{B}$ & B2 & & \\
\hline & $\mathrm{B}-$ & B3 & & \\
\hline & $\mathrm{CCC}+$ & Caa1 & \multirow{3}{*}{2} & \\
\hline & $\mathrm{CCC}$ & $\mathrm{Caa} 2$ & & \\
\hline & CCC- & $\mathrm{Caa} 3$ & & \\
\hline & $\mathrm{CC}$ & $\mathrm{Ca}$ & \multirow{3}{*}{1} & \\
\hline & $\mathrm{C}$ & $\mathrm{C}$ & & \\
\hline & $\mathrm{D} / \mathrm{SD}$ & & & \\
\hline
\end{tabular}


Variables measured on an ordinal scale such as a rating do not exhibit a measure of actual magnitude in absolute terms. What can be inferred is only the order among values, but not the difference between them. Thus, an AAA, which receives a value of 16 on a numerical scale, cannot be regarded as twice as good as a BBB, whose value is eight on a numerical scale.

Regarding ordinal data, the difference between the values 15 and 16 may not be assumed to be equal to the difference between the values of 8 and 9 , for example. The most that can be said is that if the rating increases on a numerical scale, there is a monotonic relationship of growth in credit quality (Camargo, 2009).The dependent variable, the credit rating, is composed of 22 levels on Standard \& Poor's scale and 21 levels on Moody's scale.

With respect to the independent variables derived from the hypotheses, Table 4 summarizes their proxies and previous studies that have tested and confirmed their statistical significance.

Table 4

\section{Hypotheses, Proxies and Reference Literature}

\begin{tabular}{|c|c|c|}
\hline HYPOTHESES & PROXY & REFERENCE LITERATURE \\
\hline $\begin{array}{l}\text { Leverage (-) } \\
\text { LEV }\end{array}$ & $\begin{array}{l}\text { Current liabilities + Long-term } \\
\text { liabilities / Total assets }\end{array}$ & $\begin{array}{l}\text { Adams, Burton and Hardwick (2003) } \\
\text { Gray, Mirkovic and Ragunathan (2006) } \\
\text { Damasceno, Artes and Minardi (2008) } \\
\text { Shiu and Chiang (2008) }\end{array}$ \\
\hline $\begin{array}{l}\text { Profitability (+) } \\
\text { PROF }\end{array}$ & Net profit / Equity & $\begin{array}{l}\text { Bouzouita and Young (1998) } \\
\text { Adams, Burton and Hardwick (2003) } \\
\text { Kim and Gu (2004) } \\
\text { Gray, Mirkovic and Ragunathan (2006) } \\
\text { López (2007) } \\
\text { Damasceno, Artes and Minardi (2008) } \\
\text { Shiu and Chiang (2008) } \\
\text { Matousek and Stewart (2009) }\end{array}$ \\
\hline $\begin{array}{l}\text { Size (+) } \\
\text { SIZE }\end{array}$ & Natural logarithm of total assets & $\begin{array}{l}\text { Bhojraj and Sengupta (2003) } \\
\text { Kim and Gu (2004) } \\
\text { Sales (2006) } \\
\text { Sih (2006) } \\
\text { Shiu and Chiang (2008) } \\
\text { Matousek and Stewart (2009) }\end{array}$ \\
\hline $\begin{array}{l}\text { Financial coverage }(+) \\
\mathrm{COV}\end{array}$ & EBIT/ Financial expense & $\begin{array}{l}\text { Kim and Gu (2004) } \\
\text { Gray, Mirkovic and Ragunathan (2006) } \\
\text { Bone (2007) }\end{array}$ \\
\hline $\begin{array}{l}\text { Growth (+) } \\
\text { GRO }\end{array}$ & Change in annual revenues & $\begin{array}{l}\text { Bouzouita and Young (1998) } \\
\text { Shiu and Chiang (2008) }\end{array}$ \\
\hline $\begin{array}{l}\text { Liquidity (+) } \\
\text { LIQ }\end{array}$ & $\begin{array}{l}\text { Current assets / Current } \\
\text { liabilities }\end{array}$ & $\begin{array}{l}\text { Adams, Burton and Hardwick (2003) } \\
\text { Shiu and Chiang (2008) } \\
\text { Matousek and Stewart (2009) }\end{array}$ \\
\hline
\end{tabular}


Table 4 (continued)

\begin{tabular}{|c|c|c|}
\hline HYPOTHESES & PROXY & REFERENCE LITERATURE \\
\hline Corporate governance & \multirow{3}{*}{$\begin{array}{l}\text { Dummy variable: } 1 \text { for firms in the } \\
\text { Level } 2 \text { and Novo Mercado; } 0 \text { for } \\
\text { others }\end{array}$} & Bhojraj and Sengupta (2003) \\
\hline & & \multirow{2}{*}{$\begin{array}{l}\text { Ashbaugh-Skaife, Collins and LaFond } \\
(2006)\end{array}$} \\
\hline CG & & \\
\hline Control (+) & \multirow{2}{*}{$\begin{array}{l}\text { Dummy variable: } 1 \text { for government } \\
\text { control and } 0 \text { for private control }\end{array}$} & \multirow[t]{2}{*}{ Sales $(2006)^{*}$} \\
\hline CONT & & \\
\hline $\begin{array}{l}\text { Performance in the } \\
\text { financial market }(+)\end{array}$ & $\begin{array}{l}\text { Market to book }=\text { Stock Market value / } \\
\text { Equity }\end{array}$ & \multirow{4}{*}{$\begin{array}{l}\text { Variables that are unprecedented in rating } \\
\text { studies and have not been tested previously } \\
\text { by other authors }\end{array}$} \\
\hline PERF & & \\
\hline Internationalization (+) & \multirow{2}{*}{$\begin{array}{l}\text { Dummy variable: } 1 \text { for firms that } \\
\text { issues ADRs II and III levels; } 0 \text { for } \\
\text { others }\end{array}$} & \\
\hline INTER & & \\
\hline
\end{tabular}

Note. *Control was tested by Sales, B. F. (2006). Desenvolvimento de metodologia de rating baseado no modelo ordered probit (Dissertação de mestrado). Fundação Getúlio Vargas, Rio de Janeiro, Brasil., but we've adopted another proxy.

The following equation presents the panel model with ten independent variables:

$$
\begin{gathered}
y_{i t}=\beta_{0}+\beta_{1} L E V_{t-1}+\beta_{2} P_{R O F_{t-1}}+\beta_{3} \operatorname{SIZE}_{t-1}+\beta_{4} \operatorname{COV}_{t-1}+\beta_{5} G R O_{t-1}+\beta_{6} L I Q_{t-1} \\
+\beta_{7} C G_{t-1}+\beta_{8} \operatorname{CONT}_{t-1}+\beta_{9} P E R F_{t-1}+\beta_{10} I N T E R_{t-1}+\varepsilon_{i t}
\end{gathered}
$$

where $\boldsymbol{y}_{\boldsymbol{i}}$ is a non-observable latent variable that originates the credit rating, $\beta$ are parameters, $\mathrm{j}=0, \ldots, 10$ and $\varepsilon_{i t}$ are normal random errors.

As our data presented a panel structure, with 49 companies and 153 observations, we have conducted a panel data analysis to assure the validity of the statistical tests. We used the Generalized Estimating Equations (GEE) model, for an unbalanced panel, assuming errors have a poisson distribution. For all tests conducted, Wald Chi-Square was statistically significant, which shows the models' adherence. We used the Stata $11{ }^{\circledR}$ to conduct the statistical analysis. The correlation matrix for the study's independent variables is presented in Table 5:

Table 5

\section{Correlation Matrix}

\begin{tabular}{ccccccccccc}
\hline & LEV & PROF & SIZE & COV & GRO & LIQ & CG & CONT & PERF & INTER \\
\hline LEV & 1 & $.161^{*}$ & $-.405^{* *}$ & .038 & -.033 & $-.189^{*}$ & .151 & $-.490^{* *}$ & -.103 & .011 \\
PROF & & 1 & .050 & .028 & -.071 & .004 & -.007 & -.051 & $-.521^{* *}$ & -.053 \\
SIZE & & & 1 & .025 & -.087 & -.049 & $-.271^{* *}$ & $.508^{* *}$ & -.072 & $.325^{* *}$ \\
COV & & & & 1 & .050 & .122 & .027 & $-.177^{*}$ & .056 & .109 \\
GRO & & & & & 1 & -.053 & .051 & -.151 & .071 & -.008 \\
LIQ & & & & & & 1 & $.325^{* *}$ & -.147 & $.164^{*}$ & -.006 \\
CG & & & & & & 1 & $-.179^{*}$ & .060 & .001 \\
CONT & & & & & & & 1 & -.119 & .046 \\
PERF & & & & & & & & & 1 & $.177^{*}$ \\
INTER & & & & & & & & & & 1 \\
\hline
\end{tabular}

Note. $* *$ Indicates significance at $1 \%$ confidence level.* Indicates significance at $5 \%$ confidence level. 
It is worthwhile to mention that no correlation between the independent variables was higher than $70 \%$, so it was not necessary to previously exclude any variables in the previously presented model. The highest correlation found was between the variables profitability and performance, with a negative correlation of $52.1 \%$.

\section{Data and sample}

To identify the determinants of credit ratings we used Brazilian companies' current and past ratings, as well as accounting, financial and market information available in the Economática ${ }^{\circledR}$ database. Data regarding presence in Levels of Corporate Governance were collected from the BM\&FBovespa site (the São Paulo Stock Market). Data about the issuance of ADRs were found on the Brazilian Securities Commission website (Comissão de Valores Mobiliários [CVM]).

We used all credit ratings issued by Standard \& Poor's and Moody's for companies operating in Brazil, which were available at these rating agencies' databases.

Just like other prior studies (Damasceno et al., 2008; Kang \& Liu, 2007; Roje, 2005), our paper utilizes ratings of long-term domestic bonds, and does not include financial firms in the final sample, due to differences in accounting standards and interpretation of various ratios (Gray et al., 2006).

Table 6 presents the observations contained in Standard \& Poor's and Moody's databases and exclusions made due to different issues in order to arrive at this study's final sample.

Table 6

Information about the Study's Sample

\begin{tabular}{lccc}
\hline \multicolumn{1}{c}{ EXCLUSIONS } & S\&P & Moody's & TOTAL \\
\hline Total observation base & 481 & 147 & $\mathbf{6 2 8}$ \\
(-) Observations of non-public firms & 215 & 63 & $\mathbf{2 7 8}$ \\
(-) Observations of financial firms & 61 & 04 & $\mathbf{6 5}$ \\
(-) Observations of public bonds & 20 & 10 & $\mathbf{3 0}$ \\
(-) Observations with missing data & 34 & 16 & $\mathbf{5 0}$ \\
(-) Duplicates observations & 35 & 17 & $\mathbf{5 2}$ \\
\hline (=) Total observations analyzed & $\mathbf{1 1 6}$ & $\mathbf{3 7}$ & $\mathbf{1 5 3}$ \\
\hline
\end{tabular}

It is worthwhile to mention that in the cases where more than one rating was assigned for the company during the year, either by the same rating agency or not, only the first rating issued has been considered. For example, if the company received one rating in January and another in November, only the January rating was considered in our model.

The two databases together (S\&P and Moody's) had a total of 628 observations and this study's final sample consisted of a total of 153 observations, derived from 49 companies during the period 1997-2011.

\section{Results}

As already mentioned, in order to identify the determinants of credit rating in Brazil, we used a Generalized Estimating Equations (GEE) with a panel structure, with credit rating (RATING) as the dependent variable and ten independent variables, namely: leverage (LEV), profitability (PROF), size 
(SIZE), financial coverage (COV), growth (GRO), liquidity (LIQ), corporate governance (CG), control (CONT), financial market performance (PERF), and internationalization (INTER).

Table 7 provides a descriptive analysis of the quantitative dependent variables.

Table 7

Descriptive Analysis of Independent Quantitative Variables

\begin{tabular}{cccccc}
\hline Variables & N & Minimum & Maximum & Mean & $\begin{array}{c}\text { Standard } \\
\text { Deviation }\end{array}$ \\
\hline LEV & 153 & 0.30 & 1.09 & 0.63 & 0.16 \\
PROF & 153 & -2.24 & 11.00 & 0.16 & 0.97 \\
SIZE & 153 & 13.25 & 19.49 & 16.01 & 1.28 \\
COV & 153 & -178.48 & 21.13 & 0.18 & 15.18 \\
GRO & 153 & -0.60 & 2.90 & 0.24 & 0.39 \\
LIQ & 153 & 0.22 & 4.88 & 1.21 & 0.70 \\
PERF & 153 & -28.86 & 25.61 & 1.80 & 4.31 \\
\hline
\end{tabular}

As presented in Table 7, we calculated the minimum, maximum, mean and standard deviation for all seven independent variables. Corporate governance, control and internationalization were not analyzed quantitatively as they are binary variables. Regarding these three variables, the following was observed: $22.9 \%$ of the sample was listed in Level 2 and in the New Market of BM\&FBovespa; $22.2 \%$ were companies controlled by the State and $39.9 \%$ were companies cross-listed in the United Statesd with ADRs in levels II and III.

Table 8 presents a descriptive analysis of the dependent variable: rating.

Table 8

Frequency Distribution of the Dependent Variable

\begin{tabular}{ccc}
\hline Rating & N & Percentage \\
\hline $\mathbf{1}$ & 43 & $28.1 \%$ \\
$\mathbf{2}$ & 72 & $47.1 \%$ \\
$\mathbf{3}$ & 38 & $24.8 \%$ \\
\hline Total & $\mathbf{1 5 3}$ & $\mathbf{1 0 0 \%}$ \\
\hline
\end{tabular}

The majority of ratings found in the sample are those belonging to groups BB of Standard \& Poor's (BB +, BB and BB-) and Ba by Moody's (Ba1, Ba2 and Ba3), which were converted into level 4 , as described earlier. Furthermore, one might note that $71.9 \%$ of ratings are in the Speculative Grade category, while the other $28.1 \%$ were in the Investment grade category.

There are no ratings at level 7 in the sample, those belonging to group AA (AA +, AA and AA-) and AAA - in the classification adopted by Standard \& Poor's - and their equivalents in group Aa (Aa1, Aa2 and Aa3) and Aaa - Moody's ratings.

Finally, out of the three ratings at level 1, two were issued to the Metropolitana Eletricidade de São Paulo (ELETROPAULO) in 2002 and 2003, and the other was issued to the Net Serviços de Comunicação also in 2003. The ratings at level 6 were issued to Petrobras in 2004 and to the Companhia de Bebidas das Américas (AMBEV) in 2009. 
Table 9 displays the significance of the initial model.

Table 9

\section{Significance of the Initial Panel Model}

\begin{tabular}{l|l}
\hline GEE population-averaged & $\begin{array}{l}\text { model } \\
\text { company }\end{array}$ \\
Group variable: & 153 \\
\hline Number of obs & 49 \\
Number of groups & 87.70 \\
\hline Wald chi2(10) & 0.0000 \\
Prob $>$ chi2 &
\end{tabular}

The initial model consists of all ten variables and was significant at the $1 \%$ level.

Table 10 presents the results of the initial panel model, with the respective significance for each variable and coefficient.

Table 10

\section{Results of the Initial Panel Model}

\begin{tabular}{ccccc}
\hline & Coef. & Std. Err. & $\mathbf{z}$ & P>z \\
\hline LEV & -.9181874 & .1946228 & -4.72 & 0.000 \\
PROF & .0676682 & .0453362 & 1.49 & 0.136 \\
SIZE & .0373189 & .033267 & 1.12 & 0.262 \\
COV & -.0009486 & .0005064 & -1.87 & 0.061 \\
GRO & -.0682239 & .0463388 & -1.47 & 0.141 \\
LIQ & .0443729 & .0378304 & 1.17 & 0.241 \\
CG & -.0306068 & .0683893 & -0.45 & 0.654 \\
CONT & -.0912558 & .123126 & -0.74 & 0.459 \\
PERF & .0216867 & .0121431 & 1.79 & 0.074 \\
INTER & .1339771 & .0650917 & 2.06 & 0.040 \\
CONS & .5488962 & .5530447 & 0.99 & 0.321 \\
\hline
\end{tabular}

In the initial panel model, the variable leverage (LEV) was statistically significant at the $1 \%$ level and internationalization (INTER) was significant at the 5\% level. The variables financial coverage $(\mathrm{COV})$ and financial market performance (PERF) were significant at the $10 \%$ level.

Following, we've excluded all the non-significant variables, one at the time, and tested the model again as follows: first we excluded corporate governance (CG), with a significance level of 0.654 and tested all variables again; then we removed the variable control (CONT), with significance of 0.471 ; next, size (SIZE) with a significance of 0.293 and liquidity (LIQ) with a significance of 0.295 ; and finally financial coverage (COV) with 0.128 .

Table 11 shows the significance level of the final panel model. 
Table 11

\section{Significance of the Final Panel Model}

\begin{tabular}{l|l}
\hline GEE population-averaged & $\begin{array}{l}\text { model } \\
\text { company }\end{array}$ \\
Group variable: & 153 \\
\hline Number of obs & 49 \\
Number of groups & 57.03 \\
\hline Wald chi2(5) & 0.0000 \\
\hline Prob $>$ chi2
\end{tabular}

The final panel model was significant at the $1 \%$ level. Table 12 presents the results of the final panel model, with the significance for each variable and respective coefficient.

Table 12

Results of Final Panel Model

\begin{tabular}{ccccc}
\hline & Coef. & Std. Err. & $\mathbf{z}$ & P>z \\
\hline LEV & -.9602618 & .1839527 & -5.22 & 0.000 \\
PROF & .0745925 & .0452558 & 1.65 & 0.099 \\
GRO & -.0803098 & .0470839 & -1.71 & 0.088 \\
PERF & .0229738 & .0111409 & 2.06 & 0.039 \\
INTER & .1609862 & .0573787 & 2.81 & 0.005 \\
_CONS & 1.18955 & .1085322 & 10.96 & 0.000 \\
\hline
\end{tabular}

In the final panel model, the variables leverage (LEV), and internationalization (INTER) were statistically significant at the $1 \%$ level; financial market performance (PERF) was statistically significant at the $5 \%$ level. The variables profitability (PROF) and growth (GRO) were also relevant, but at the $10 \%$ level.

One might note that the two new variables proposed by this study - performance and internationalization - were found to be relevant factors in explaining credit rating of companies operating in Brazil.

Regarding the expected signals, the variable growth presented a sign contrary to what was expected, as our hypothesis was that firms with higher growth rates would present better credit ratings.

\section{Conclusions}

This study aimed to identify the determinants of credit ratings in Brazil. To this end, we built a Generalized Estimating Equations (GEE) model using a panel structure with credit rating as the dependent variable and ten other independent variables, namely: leverage, profitability, size, financial coverage, growth, liquidity, corporate governance, control, financial market performance, and internationalization. The sample comprised a total of 153 credit rating observations issued to companies operating in Brazil during the period 1997-2011 by two major global agencies: Standard \& Poor's and Moody's. 
The empirical results showed that five variables are statistically significant: leverage, profitability, growth, financial market performance, and internationalization.

The two variables introduced by this study proved to be significant: financial market performance, measured by the ratio of market value of shares and equity, was significant at a $5 \%$ level and internationalization, a dummy variable indicating whether the company had issued ADRs of levels II or III, was significant at a $1 \%$ level. As an indication for future work, we suggest the analysis of the determinant factors of credit rating in other countries, as the great majority of previous studies regarding the determinants of credit rating have been conducted in the USA, UK and Australia, so the effect in other markets is still unclear, especially in emerging economies.

\section{Acknowledgments}

We would like to thank CAPES, CNPq and IAAER/Deloitte for financial support.

\section{References}

Adams, M., Burton, B., \& Hardwick, P. (2003). The determinants of credit ratings in the United Kingdom insurance industry. Journal of Business Finance \& Accounting, 30(3/4), 539-572. doi: $10.1111 / 1468-5957.00007$

Altman, E. (1968). Financial ratios, discriminant analysis and the prediction of corporate bankruptcy. The Journal of Finance, 23(4), 589-609. doi: 10.1111/j.1540-6261.1968.tb00843.x

Ashbaugh-Skaife, H., Collins, D., \& LaFond, R. (2006). The effects of corporate governance on firms' credit ratings. Journal of Accounting and Economics, 42(1), 203-243. doi: 10.1016/j.jacceco.2006.02.003

Bernstein, P. (1997). Desafio aos deuses: a fascinante história do risco (I. Korytowski, Trad.). Rio de Janeiro: Campus. (Obra original publicada em 1996)

Bhojraj, S., \& Sengupta, P. (2003). Effect of corporate governance on bond ratings and yields: the role of institutional investors and outside directors. The Journal of Business, 76(3), 455-476. doi:10.2139/ssrn.291056

Bone, R. B. (2007). Determinantes de ratings corporativos no setor de petróleo: o caso da Petrobrás. RAC-Eletrônica, $\quad 1(3), \quad 107-125 . \quad$ Retrieved from http://www.anpad.org.br/periodicos/arq_pdf/a_667.pdf

Bone, R. B. (2010). Determinantes dos ratings corporativos na indústria petrolífera: o caso da RepsolYPF. Revista Eletrônica de Administração, 16(1), 1-21. Retrieved from file://C:/Users/RAC/Downloads/38977-155048-1-PB.pdf

Bone, R. B., \& Ribeiro, E. P. (2009, julho/agosto). Conteúdo informacional dos ratings corporativos de empresas brasileiras, 1995-2007. Anais do Encontro Brasileiro de Finanças, São Leopoldo, RS, Brasil, 9.

Bouzouita, R., \& Young, A. (1998). A probit analysis of best ratings. Journal of Insurance Issues, 21(1), 23-34.

Calderoni, F., Colla, P., \& Gatti, S. (2009). Ratings changes: the European evidence [Working Paper]. Social Science Research Network. Retrieved from http://ssrn.com/abstract=1410646 
Callado, A. A. C., Vasconcelos, M. M. F., Rodrigues, R. N., \& Libonati, G. (2008). O impacto da primeira emissão de conceito de risco crédito sobre os preços das ações: um estudo empírico sobre a reação do mercado acionário brasileiro para o setor bancário. Revista Ciências Administrativas, 14(1), 80-88.

Camargo, A. C. B. (2009). Bônus corporativos: um estudo sobre as variáveis que afetam o rating de uma emissão (Dissertação de mestrado). Programa de Pós-Graduação em Administração de Empresas, Pontifícia Universidade Católica do Rio de Janeiro, Rio de Janeiro, Brasil.

Camargos, M. A., Gomes, G. D., \& Barbosa, F. V. (2003). Integração de mercados e arbitragem com títulos transfronteiriços: ADR - American Depository Receipts. Caderno de Pesquisas em Administração, 10(2), 51-67.

Cantor, R., \& Packer, F. (1997). Differences of opinion and selection bias in the credit rating industry. Journal of Banking \& Finance, 21(10), 1395-1417. doi: 10.1016/S0378-4266(97)00024-1

Choy, E. Y. W., Gray, S. F., \& Ragunathan, V. (2006). Effect of credit rating changes on Australian stock returns. Accounting and Finance, 46(5), 755-769. doi: 10.1111/j.1467-629X.2006.00192.x

Coffee, J. C., Jr. (1999). The future as history: the prospects for global convergence in corporate governance and its implications. Northwestern University Law Review, 93(3), 641-707.

Creighton, A., Gower, L., \& Anthony, J. R. (2007). The impact of rating changes in Australian financial markets. Pacific-Basin Finance Journal, 15(1), 1-17. doi: 10.1016/j.pacfin.2006.04.003

Damasceno, D. L., Artes, R., \& Minardi, A. M. C. F. (2008). Determinação de rating de crédito de empresas brasileiras com a utilização de índices contábeis. Revista de Administração, 43(4), 344-355.

Ferri, G., \& Liu, L.-G. (2002). Do global credit rating agencies think globally? The information content of firm ratings around the world. Retrieved from http://repec.org/res2002/Ferri.pdf

Fitch Ratings. (n.d.). Ratings internacionais de crédito de longo prazo. Retrieved from http://www.fitchratings.com.br/pages/rtg_intl_long

Gray, S., Mirkovic, A., \& Ragunathan, V. (2006). The determinants of credit ratings: Australian evidence. Australian Journal of Management, 31(2), 333-354. doi: $10.1177 / 031289620603100208$

Guerron-Quintana, P. A. (2011). Risk and uncertainty. Business Review, Q1, 10-18.

Gujarati, D. (2006). Econometria básica (M. J. C. Monteiro, Trad.). Rio de Janeiro: Elsevier. (Obra original publicada em 1975)

Han, S. H., Shin, Y. S., Reinhart, W., \& Moore, W. T. (2009). Market segmentation effects in corporate credit rating changes: the case of emerging markets. Journal of Financial Services Research, 35(2), 141-166. doi: 10.1007/s10693-008-0049-0

Jorion, P., Liu, Z., \& Shi, C. (2005). Informational effects of regulation FD: evidence from rating agencies. Journal of Financial Economics, 76(2), 309-330. doi: 10.1016/j.jfineco.2004.05.001

Kang, Q., \& Liu, Q. (2007). Credit rating changes and CEO incentives [Working Paper]. Social Science Research Network. Retrieved from http://ssrn.com/abstract=971277

Kaplan, R. S., \& Urwitz, G. (1979). Statistical models of bond ratings: a methodological inquiry. The Journal of Business, 52(2), 231-261. 
Kim, H., \& Gu, Z. (2004). Financial determinants of corporate bond ratings: an examination of hotel and casino firms. Journal of Hospitality \& Tourism Research, 28(1), 95-108. doi: $10.1177 / 1096348003261217$

La Porta, R., Lopes-de-Silanes, F., Schleifer, A., \& Vishny, R. W. (1997). Legal determinants of external finance. The Journal of Finance, 52(3), 1131-1150. doi: 10.1111/j.15406261.1997.tb02727.x

La Porta, R., Lopes-de-Silanes, F., Schleifer, A., \& Vishny, R. W. (1999). The quality of government. The Journal of Law, Economics and Organization, 15(1), 222-279. doi: 10.1093/jleo/15.1.222

La Porta, R., Lopes-de-Silanes, F., Schleifer, A., \& Vishny, R. W. (2000). Investor protection and corporate governance. Journal of Financial Economics, 58(1/2), 3-27. doi: 10.1016/S0304405X(00)00065-9

La Porta, R., Lopes-de-Silanes, F., Schleifer, A., \& Vishny, R. W. (2002). Investor protection and corporate valuation. The Journal of Finance, 57(3), 1147-1170. doi: 10.1111/1540-6261.00457

Liang, K. Y., \& Zeger, S. L. (1986). Longitudinal data analysis using generalized linear models. Biometrika, 73(1), 13-22. doi: 10.1093/biomet/73.1.13

Lopes, A., \& Walker, M. (2012). Asset revaluations, future firm performance and firm-level corporate governance arrangements: new evidence from Brazil. The British Accounting Review, 44(2), 5367. doi: 10.1016/j.bar.2012.03.007

López, R. F. (2007). Análisis de los determinantes del riesgo de crédito: aplicación de técnicas emergentes em el marco de los acuerdos de Basilea II y Solvencia II. Revista Española de Financiación y Contabilidad, 36(135), 649-653.

Markowitz, H. (1952). Portfolio selection. The Journal of Finance, 7(1), 77-91. doi: 10.1111/j.15406261.1952.tb01525.x

Matousek, R., \& Stewart, C. (2009). A note on ratings of international banks. Journal of Financial Regulation and Compliance, 17(2), 146-155. doi: 10.1108/13581980910952586

Moody's Investors Service. (2013). Ratings symbols and definitions. Retrieved from https://www.moodys.com/researchdocumentcontentpage.aspx?docid=PBC_79004

Papaikonomou, V. L. (2010). Credit rating agencies and global financial crisis: need for a paradigm shift in financial market regulation. Studies in Economics and Finance, 27(2), 161-174. doi: $10.1108 / 10867371011048643$

Pinches, G. E., \& Singleton, J. C. (1978). The adjustment of stock prices to bond rating changes. The Journal of Finance, 33(1), 29-44. doi: 10.1111/j.1540-6261.1978.tb03387.x

Poon, W. P. H., \& Chan, K. C. (2008). An empirical examination of the informational content of credit ratings in China. Journal of Business Research, 61(7), 790-797. doi: 10.1016/j.jbusres.2007.08.001

Richards, A., \& Deddouche, D. (2003). Bank rating changes and bank stock returns: puzzling evidence from the emerging markets. Journal of Emerging Market Finance, 2(3), 337-363. doi: $10.1177 / 097265270300200304$

Roje, G. (2005, May). The role of accounting determinants in predicting long term credit ratings. Proceedings of the European Accounting Association Congress, Gotheborg, Sweden, 28.

Sales, B. F. (2006). Desenvolvimento de metodologia de rating baseado no modelo ordered probit (Dissertação de mestrado). Fundação Getúlio Vargas, Rio de Janeiro, Brasil. 
Shiu, Y., \& Chiang, C. (2008). Determinants of financial strength ratings: evidence from the Lloyd's Market. Retrieved from http://portal.business.colostate.edu/projects/ARIA/Shared\%20Documents/2a_Shiu_Determinant s\%20of\%20Financial\%20Strength\%20Ratings.pdf

Sih, A. (2006). Predição do grau de ratings corporativos (Dissertação de mestrado). Programa de PósGraduação do Departamento de Engenharia Elétrica, Pontifícia Universidade Católica do Rio de Janeiro, Rio de Janeiro, Brasil.

Silva, E., Santos, J., Torres, F., \& Ferreira, L. (2009, setembro). Os efeitos da governança corporativa sobre os ratings de crédito das debêntures emitidas por empresas listadas nos níveis diferenciados de governança da Bovespa. Anais do Encontro Nacional da Associação Nacional de Pós-Graduação e Pesquisa em Administração, São Paulo, SP, Brasil, 33.

Standard \& Poor's Ratings Services. (2010). Guide to credit ratings criteria: Why criteria are important and how they are applied. Retrieved from http://pt.scribd.com/doc/142361735/Guideto-Credit-Ratings-Criteria

Standard \& Poor's Ratings Services. (2011). Guide to credit rating essentials: what are credit ratings and how do they work? Retrieved from http://img.en25.com/Web/StandardandPoors/SP_CreditRatingsGuide.pdf 